\title{
Estimation and Economic Valuation of Above-Ground Carbon in Forest Area with the Special Purpose of Gunung Bromo, Karanganyar, Central Java, Indonesia
}

\author{
Rissa Rahmadwiati ${ }^{*}$, Rezky Lasekti Wicaksono, Dwi Apriyanto \\ Department of Forest Management, Faculty of Agriculture, Universitas Sebelas Maret. Jl. Ir. Sutami No. 36 A, Surakarta, 57126 , \\ Central Java, Indonesia \\ *Corresponding Author. E-mail address: rahmadwiati.r@staff.uns.ac.id
}

\section{ARTICLE HISTORY:}

Received: 9 August 2021 Peer review completed: 16 November 2021 Received in revised form: 17 January 2022 Accepted: 24 February 2022

\section{KEYWORDS:}

Biomas

Carbon estimation

Economic valuation

KHDTK of Gunung Bromo
(C) 2022 The Author(s). Published by Department of Forestry, Faculty of Agriculture, University of Lampung in collaboration with Indonesia Network for Agroforestry Education (INAFE)

This is an open access article under the CC BY-NC license:

https://creativecommons.org/licenses/bync $/ 4.0 \%$.

\begin{abstract}
Climate change and the increasing greenhouse effect are serious problems of global concern today. The existence of forests plays an essential role in carbon sequestration and storage to reduce greenhouse gas (GHG) concentration in the atmosphere. Forest Area with the Special Purpose (KHDTK) of Gunung Bromo has an area of 126,291 ha that is designated as an educational forest. The area has been managed by Universitas Sebelas Maret since 2019 and consists of three main tree species, namely Pinus merkusii, Swietenia mahagoni, and Dalbergia latifolia. This study aims to estimate the potential uptake and economic valuation of carbon stocks in the KHDTK of Gunung Bromo. Stratified Systematic Sampling with Random Start was used as an inventory method in this study. The estimation of above-ground carbon uptake used general allometric equations (non-destructive method). Furthermore, the carbon economy valuation referred to the range of calculating the average carbon price for each program specification. The results showed that the estimated carbon of tree stands in KHDTK of Gunung Bromo reached 75.81 tonnes C/ha with a carbon economic valuation of USD 758.1/ha or equivalent to IDR 10,856,863.80/ha. Exploring the potential for biodiversity (flora and fauna) and environmental services such as carbon sink will support the ecotourism program in KHDTK of Gunung Bromo.
\end{abstract}

\section{Introduction}

Global warming is a form of ecosystem imbalance due to the increasing average temperature of the earth's atmosphere, sea, and land (Rizki et al. 2009). Global warming occurs when the earth experiences years of rising temperature caused by climate change. Climate change is due to increased carbon dioxide concentrations derived from fossil fuels resulting from various human activities. Due to global warming, there has been an increase in the average temperature of the earth's seas and land caused by industrial activity and reduced land cover, especially forests, due to the rate of deforestation (Wardhana 2011; Yuniawati and Tampubolon 2021).

Forests absorb $\mathrm{CO}_{2}$ during photosynthesis and store it as organic matter in plant biomass. The amount of organic matter stored in forest biomass per unit area and per unit time is the basis of forest productivity, which illustrates forest ability to reduce $\mathrm{CO}_{2}$ emissions in the atmosphere through their physiological activities (Yulistyarini et al. 2009). Forests also have an essential role 
and benefit life both directly and indirectly. According to Zainuddin and Tahnur (2018), one of the efforts to solve the problem of climate change is to improve the quality of forests to maintain their ecological function. Given the importance of the role of the forest in the absorption and storage of carbon in biomass, research is needed to encourage the continued development of carbon assessment methods in biomass. In addition to ecological functions, forests also have economic and socio-cultural functions that must be balanced and dynamic to support national development. Therefore, forests must be managed, protected, and utilized continuously for the welfare of the people. Furthermore, the negotiations on reducing emissions from deforestation and forest degradation, as well as the role of conservation, sustainable forest management, and enhancement of forest carbon stock in developing countries during the commitment period of post-Kyoto Protocol, also led to more attention being focused on the methodology of biomass and carbon stock estimation (UNFCCC 2009).

The Ministry of Environment and Forestry authorized Universitas Sebelas Maret (UNS) in 2018 to manage Forest Area with Special Purpose (KHDTK) of Gunung Bromo in Karanganyar, Central Java, Indonesia. KHDTK of Gunung Bromo was initially a forest area that functioned as tourism and was managed by Surakarta Forest Management Unit (KPH) Perhutani. KHDTK of Gunung Bromo has an area of 126,291 ha. Based on management, the area of KHDTK of Gunung is divided into blocks with several potentials that can be utilized for development and research in forest management, forest use and forest products, and ecotourism.

The potential is in the form of biological and non-biological potential. This area has the potential of forest resources in plant forests dominated by Pinus merkusii, Swietenia mahagoni, and Dalbergia latifolia. Apart from being overgrown with Pinus merkusii for their sap to be extracted as the main commodity, the forest area in KHDTK of Gunung Bromo is also overgrown with various plants in the form of trees, bamboo, shrubs, and herbs.

Kepel et al. (2017) stated that the determination of the important value of ecosystems and being able to be done with ecological approaches also through the economic valuation of each function of biotic and abiotic components in those ecosystems. According to Rochmayanto et al. (2010), the value of the carbon economy is one of the values of environmental services that can be used as a criterion for decision making. This research aims to discover the potential of carbon deposits and obtain the economic value of carbon in the forest area of KHDTK of Gunung Bromo. It is crucial because there is no information regarding the potential valuation of the carbon economy stored in KHDTK Gunung Bromo. Exploring the potential for biodiversity (flora and fauna) and environmental services such as carbon sink will support the ecotourism program in KHDTK of Gunung Bromo. Programs can be developed at KHDTK of Gunung Bromo to take advantage of biodiversity, landscape beauty, and carbon conservation in the forest, namely ecotourism such as forest healing tourism, beekeeping, bird watching, and trees adoption. In addition, the future management of KHDTK of Gunung Bromo is also expected to be an essential spotlight in the development of ecotourism which will later become a unique attraction for people in Central Java Province in particular Indonesia and even internationally in general. 


\section{Materials and Methods}

\subsection{Study area}

The study was conducted in KHDTK of Gunung Bromo, Karanganyar, Central Java, Indonesia. KHDTK of Gunung Bromo is managed by Universitas Sebelas Maret, which is expected to explore the potential of existing biodiversity to the fullest and wisely create environmental sustainability by maintaining biodiversity and minimizing climate change. KHDTK of Gunung Bromo is geographically located at $7^{\circ} 34^{\prime} 21.93^{\prime \prime}-7^{\circ} 35^{\prime} 38.90^{\prime \prime} \mathrm{S}$ and $110^{\circ} 59^{\prime} 40.39^{\prime \prime}-$ $111^{\circ} 0^{\prime} 49.36^{\prime \prime}$ E (Fig. 1). Furthermore, KHDTK of Gunung Bromo is administratively located in Delingan, Gedong, and Sewurejo villages with the following regional boundaries (UPT Pusdiklathut 2019):

1. North: Sewurejo Village, Mojogedang District,

2. South: Delingan and Gedong Village, Karanganyar District,

3. West: Gedong Village, Karanganyar District,

4. East: Delingan Village, Karanganyar District.

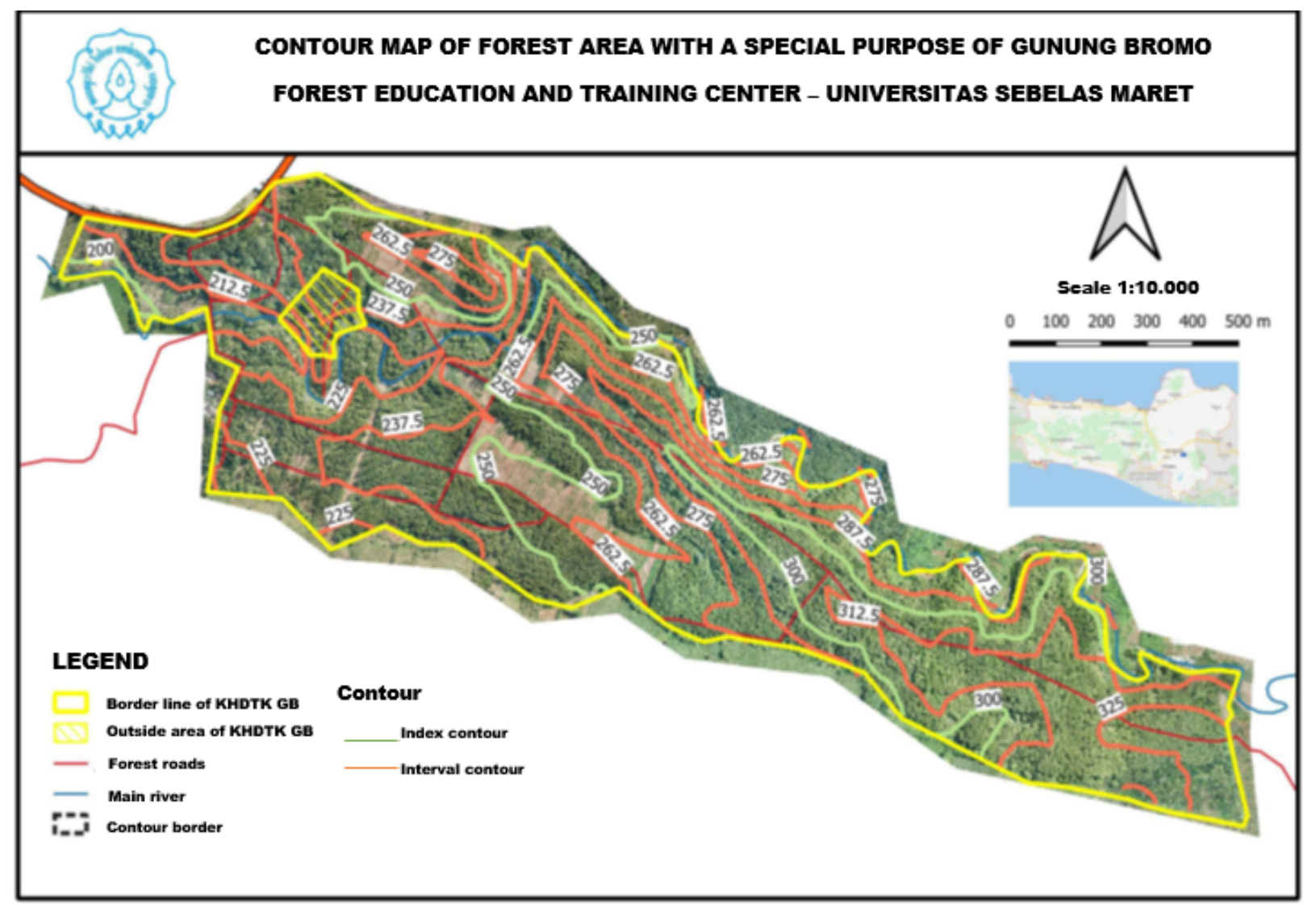

Fig. 1. Maps of KHDTK of Gunung Bromo Karanganyar (UPT Pusdiklathut UNS).

Gunung Bromo Forest is a production forest that dominated by Pinus merkusii, Swietenia mahagoni, and Dalbergia latifolia. It is located at 200-337.5 masl with a rainfall of 190 $\mathrm{mm} /$ month. The region's average temperature is $26-27^{\circ} \mathrm{C}$ with a relative humidity of $70-83 \%$. Based on Schmidt and Ferguson's classification, the type of rainfall in the region is classified as type $\mathrm{C}$, which is a rather wet, wooded area with leaves that fall in the dry season. Finally, the soil types in this area are alfisol and inceptisol. 


\subsection{Method}

Inventory activities were carried out to acquire the timber potential of KHDTK of Gunung Bromo. The activity used a sampling intensity of 5\% of the total area of Gunung Bromo Forest, covering an area of 126,291 ha. The sampling plots were determined using stratified systematic sampling with a random start with a circular sampling plot having a radius of $17.8 \mathrm{~m}$, or an area of 0.1 ha. The number of sampling plots was as many as 60 plots. The data collected include the name of the tree species, diameter at breast height (dbh), and tree height. Diameter measurements were carried out on pole-level stands starting from 10-20 cm diameter and tree-level stands with a diameter $>20 \mathrm{~cm}$.

Calculation of tree biomass above-ground level on KHDTK of Gunung Bromo used common allometric equations. Such equations are an alternative to a more simple and costeffective approach than destructive methods (Khan et al. 2020). The allometric equations used in estimating tree biomass above-ground level are as follows (Chave et al. 2014; Khan et al. 2020):

$$
A G B=0.0673 \times\left(\rho D^{2} H\right)^{0.976}
$$

where $A G B$ is above-ground biomass $(\mathrm{kg} /$ tree $), D$ is the diameter at breast height $(\mathrm{cm}), H$ is tree height $(\mathrm{m})$, and $\rho$ is wood density $\left(\mathrm{g} / \mathrm{cm}^{3}\right)$.

The equation is a proper biomass guessing model for pan-tropic countries and can be used well in all types of forests and bioclimatic conditions (Chave et al. 2014). A generalized linear model of stand-level carbon stocks showed significant relationships to stand basal area, wood density, mean tree height, and maximum/dominant tree height (Khan et al. 2020). Furthermore, because the tree's carbon stock does not reach 50\% and is in the range of 45-50\% (Kauffman and Donato 2012; Zhang et al. 2016), then we use the number 0.47 (47\%) as a multiply of tree biomass estimates to obtain an estimation of above-ground carbon (AGC) (Dong et al. 2020; Khan et al. 2020). Finally, each sample plot's last individual AGC tree is summed and converted into stand carbon stock (Mg/ha) for each species (Khan et al. 2020).

Forest biomass can be used to estimate carbon stores stored in vegetation because $50 \%$ of the biomass is composed of carbon (Brown 1997) so that the results of the biomass calculation can be changed in the form of carbon (ton/ha) by multiplying the biomass value by the conversion factor of 0.5 .

$$
\text { Carbon }(C)=\text { Biomass } x 0.5
$$

The economic valuation of carbon depends on the goals and standards of the world economy (Perez-Verdin et al. 2016). Based on the Deforestation and Forest Degradation Reduction (REDD) Program, the average carbon price for land change prevention and reforestation projects in 2010 was USD 5 and $9 / \mathrm{tCO}_{2} \mathrm{e}$, respectively. As for the REDD+ program, the maximum price is around USD $25 / \mathrm{tCO}_{2} \mathrm{e}$, and the carbon price related to the forest management improvement program is around USD 136/ $\mathrm{tCO}_{2}$ e (Perez-Verdin et al. 2016; Peters-Stanley and Hamilton 2012; Torres et al. 2015). In determining the economic value of carbon, the approach used is a proxy market approach where the carbon price is USD 10/ton (Hutajulu and Afifah 2019).

\section{Results and Discussion}

Forests have a role to play in absorbing $\mathrm{CO}_{2}$ in the atmosphere through chlorophyll vegetation and are aided by abiotic factors such as sunlight and water. Forests consisting of trees in the growth phase will absorb more $\mathrm{CO}_{2}$, while forests that have slowed their growth can only 
store carbon stocks. Carbon stocks are stored in biomass or forest ecosystems (Ministry of Forestry 2013). Therefore, the sustainable forest amount of stored carbon will continue to grow. The carbon in this stand will be stored in the form of biomass.

KHDTK of Gunung Bromo is a plantation forest dominated by Pinus merkusii, Swietenia mahagoni, and Dalbergia latifolia. The area has considerable potential in efforts to increase carbon absorption. For example, Drupadi et al. (2021) stated that P. merkusii land cover produces the highest tree biomass and stored carbon compared to mixed land cover. The distribution of potential stands in KHDTK of Gunung Bromo is presented in Table 1.

Table 1. The stands distribution in the KHDTK of Gunung Bromo

\begin{tabular}{lcc}
\hline Tree species & Frequency & Percentage (\%) \\
\hline Pinus merkusii & 1,306 & 67.80 \\
Swietenia mahagoni & 471 & 24.45 \\
Dalbergia latifolia & 36 & 1.87 \\
Others & 113 & 5.87 \\
\hline Total & 1,926 & 100.00 \\
\hline
\end{tabular}

The analysis was carried out on 60 plots size 0.1 ha/plot, with varying trees in each plot. Table 1 shows that the distribution of the stand's potential is dominated by P. merkusii, followed by $S$. mahagoni, D. latifolia, and other species. KHDTK of Gunung Bromo is a monoculture forest dominated by $P$. merkusii as the main tree previously managed by Perhutani. P. merkusii was selected as it is commonly planted in industrial plantations in Java. In addition, some certain areas outside of Java preferred this species due to various advantages in terms of technical, economic, ecological, and social (Sallata 2013). S. mahagoni and D. latifolia are interesting to be managed for long-term wood production. The other species, such as Tectona grandis, Durio zibethinus, and Albizia chinensis, were existed in a small number.

Table 2 shows that the diameter class of the tree is varied in each species. P. merkusii consists of 13 diameter classes, S. mahagoni consists of 10 diameter classes, D. latifolia consists of 4 diameter classes, and other species consists of 10 diameter classes. The number of trees in each class of diameter shows varying numbers. The most frequency in $P$. merkusii was the diameter class of 4 with a diameter interval of $0.20-0.23 \mathrm{~m}$. S. mahagoni has the most frequency in the diameter class of 3 with a diameter interval of $0.21-0.30 \mathrm{~m}$, while D. latifolia has the most frequency in diameter class of 1 with a diameter interval of $0.08-0.16 \mathrm{~m}$. In KHDTK of Gunung Bromo, about $80 \%$ of the area is dominated by monoculture forests extending to the eastern part of the region. This monoculture forest is planted with $P$. merkusii for daily production previously managed by Perhutani, while the rest is an intercropping of $S$. mahagoni and D. latifolia.

The results showed that the larger the diameter class, the fewer stand frequency (Table 2). Variations in diameter classes on each type of stand can be influenced by habitat conditions and the level of competition of each individual. This is in line with Pebriandi et al. (2014), stating that competition in obtaining nutrients, sunlight, water, and growing space affected plant growth. In this study, trees with large diameter classes were unable to compete, resulting in fewer frequencies.

$\mathrm{CO}_{2}$ is one of the important components in photosynthesis. During photosynthesis, trees will absorb $\mathrm{CO}_{2}$ and compose carbohydrates, which will then be stored in the form of biomass (Uthbah et al. 2017). Thus, the amount of biomass produced can be used to determine the number of carbon stocks or the amount of $\mathrm{CO}_{2}$ absorbed by trees. Tree biomass value is directly proportional to the 
carbon value because carbon content will follow each addition of biomass content. The biomass amount of each species in KHDTK of Gunung Bromo is presented in Table 3. The highest biomass was observed in P. merkusii, mainly dominated by the diameter class of 7 of $22,133.47 \mathrm{~kg} / \mathrm{ha}$.

Table 2. The diameter class distribution of each species in KHDTK of Gunung Bromo

\begin{tabular}{|c|c|c|c|}
\hline Tree species & Dbh class & The interval of dbh (m) & Frequency \\
\hline \multirow{13}{*}{ Pinus merkusii } & 1 & $0.08-0.11$ & 35 \\
\hline & 2 & $0.12-0.15$ & 105 \\
\hline & 3 & $0.16-0.19$ & 141 \\
\hline & 4 & $0.20-0.23$ & 226 \\
\hline & 5 & $0.24-0.27$ & 208 \\
\hline & 6 & $0.28-0.31$ & 215 \\
\hline & 7 & $0.32-0.35$ & 167 \\
\hline & 8 & $0.36-0.39$ & 105 \\
\hline & 9 & $0.40-0.43$ & 63 \\
\hline & 10 & $0.44-0.47$ & 25 \\
\hline & 11 & $0.48-0.51$ & 11 \\
\hline & 12 & $0.52-0.55$ & 4 \\
\hline & 13 & $0.56-0.59$ & 1 \\
\hline \multirow[t]{10}{*}{ Swietenia mahagoni } & 1 & $0.01-0.10$ & 3 \\
\hline & 2 & $0.11-0.20$ & 129 \\
\hline & 3 & $0.21-0.30$ & 190 \\
\hline & 4 & $0.31-0.40$ & 120 \\
\hline & 5 & $0.41-0.50$ & 18 \\
\hline & 6 & $0.51-0.60$ & 5 \\
\hline & 7 & $0.61-0.70$ & 1 \\
\hline & 8 & $0.71-0.80$ & 2 \\
\hline & 9 & $0.81-0.90$ & 1 \\
\hline & 10 & $0.91-1.00$ & 2 \\
\hline \multirow[t]{4}{*}{ Dalbergia latifolia } & 1 & $0.08-0.16$ & 18 \\
\hline & 2 & $0.17-0.25$ & 16 \\
\hline & 3 & $0.26-0.34$ & 1 \\
\hline & 4 & $>0.35$ & 1 \\
\hline \multirow[t]{10}{*}{ Others } & 1 & $0.07-0.17$ & 32 \\
\hline & 2 & $0.18-0.28$ & 35 \\
\hline & 3 & $0.29-0.39$ & 27 \\
\hline & 4 & $0.40-0.50$ & 3 \\
\hline & 5 & $0.51-0.61$ & 8 \\
\hline & 6 & $0.62-0.72$ & 3 \\
\hline & 7 & $0.73-0.83$ & 1 \\
\hline & 8 & $0.84-0.94$ & 1 \\
\hline & 9 & $0.95-1.05$ & 2 \\
\hline & 10 & $1.06-1.16$ & 1 \\
\hline
\end{tabular}

Table 3 shows that the highest biomass on $S$. mahagoni stands was in the diameter class 4 of $13,060.35 \mathrm{~kg} / \mathrm{ha}$, and in D. latifolia stands was in the diameter class of 2 of $566.42 \mathrm{~kg} / \mathrm{ha}$. The rest of the species has the highest biomass in the diameter class of 3 of $3,678.91 \mathrm{~kg} / \mathrm{ha}$. The results showed that the larger the class of tree diameter in each species does not show the greater the amount of biomass, but rather depends on the frequency or number of trees in each species. The total biomass of all species in KHDTK of Gunung Bromo was 161,306.75 kg/ha. 
Table 3. The biomass of each species in KHDTK of Gunung Bromo

\begin{tabular}{|c|c|c|c|}
\hline $\begin{array}{l}\text { Tree species } \\
\end{array}$ & Dbh Class & Interval of dbh (m) & Biomass (kg/ha) \\
\hline \multirow{13}{*}{ Pinus merkusii } & 1 & $0.08-0.11$ & 335.49 \\
\hline & 2 & $0.12-0.15$ & $1,136.11$ \\
\hline & 3 & $0.16-0.19$ & $4,263.18$ \\
\hline & 4 & $0.20-0.23$ & $8,526.38$ \\
\hline & 5 & $0.24-0.27$ & $14,466.88$ \\
\hline & 6 & $0.28-0.31$ & $19,131.77$ \\
\hline & 7 & $0.32-0.35$ & $22,133.47$ \\
\hline & 8 & $0.36-0.39$ & $15,380.54$ \\
\hline & 9 & $0.40-0.43$ & $10,582.96$ \\
\hline & 10 & $0.44-0.47$ & $6,416.23$ \\
\hline & 11 & $0.48-0.51$ & $2,202.34$ \\
\hline & 12 & $0.52-0.55$ & 880.06 \\
\hline & 13 & $0.56-0.59$ & 412.00 \\
\hline Total & & & $105,867.40$ \\
\hline \multirow{10}{*}{ Swietenia mahagoni } & 1 & $0.01-0.10$ & 9.53 \\
\hline & 2 & $0.11-0.20$ & $2,551.35$ \\
\hline & 3 & $0.21-0.30$ & $9,408.59$ \\
\hline & 4 & $0.31-0.40$ & $13,060.35$ \\
\hline & 5 & $0.41-0.50$ & $3,319.29$ \\
\hline & 6 & $0.51-0.60$ & $1,334.70$ \\
\hline & 7 & $0.61-0.70$ & 675.82 \\
\hline & 8 & $0.71-0.80$ & 1566.40 \\
\hline & 9 & $0.81-0.90$ & 997.27 \\
\hline & 10 & $0.91-1.00$ & $3,980.59$ \\
\hline Total & & & $36,903.89$ \\
\hline \multirow[t]{4}{*}{ Dalbergia latifolia } & 1 & $0.08-0.16$ & 265.56 \\
\hline & 2 & $0.17-0.25$ & 566.42 \\
\hline & 3 & $0.26-0.34$ & 76.28 \\
\hline & 4 & $>0.35$ & 432.33 \\
\hline Total & & & $1,340.59$ \\
\hline \multirow[t]{10}{*}{ Others } & 1 & $0.07-0.17$ & 475.15 \\
\hline & 2 & $0.18-0.28$ & $2,293.13$ \\
\hline & 3 & $0.29-0.39$ & $3,678.91$ \\
\hline & 4 & $0.40-0.50$ & 523.55 \\
\hline & 5 & $0.51-0.61$ & $2,879.92$ \\
\hline & 6 & $0.62-0.72$ & $1,352.53$ \\
\hline & 7 & $0.73-0.83$ & 771.20 \\
\hline & 8 & $0.84-0.94$ & $1,193.50$ \\
\hline & 9 & $0.95-1.05$ & $2,513.76$ \\
\hline & 10 & $1.06-1.16$ & $1,513.22$ \\
\hline Total & & & $17,194.86$ \\
\hline
\end{tabular}

The value of carbon stock is determined by measuring the biomass of the stand at pole and tree growth stages. Once the above-ground biomass data is known, the carbon stored in the stands in the KHDTK of Gunung Bromo was estimated. The carbon stored data is presented in Table 4. The results showed that the estimated total carbon stock contained in KHDTK of Gunung Bromo was $75.81 \mathrm{Mg} / \mathrm{ha}$ or 75.81 tonnes $\mathrm{C} / \mathrm{ha}$. The highest carbon stock is obtained from pine stands at $49.76 \mathrm{Mg} / \mathrm{ha}$. This is because pine stands have the most frequency among other stands. The high value of biomass and carbon stock in the land with $P$. merkusii cover is presumably due to tree height parameters that affected the biomass of the trees (Drupadi et al. 2021). Bismark et al. (2008) stated that the increase in biomass and carbon stocks is due to the size of the trees, particularly the 
tree height parameter. The value of carbon absorption in KHDTK of Gunung Bromo is 75.81 tonnes $\mathrm{C} /$ ha following the conditions of plantation forest in Java Island capable of absorbing carbon in the range of 42.17 tonnes $\mathrm{C} / \mathrm{ha}-144.41$ tonnes C/ha (Rochmayanto et al. 2014).

Table 4. The carbon stock of stand in KHDTK of Gunung Bromo

\begin{tabular}{lcc}
\hline Tree species & Total carbon stock (kg/ha) & Total carbon stock Mg/ha) \\
\hline Pinus merkusii & $49,757.68$ & 49.76 \\
Swietenia mahagoni & $17,344.83$ & 17.34 \\
Dalbergia latifolia & 630.08 & 0.63 \\
Others & $8,081.59$ & 8.08 \\
\hline Total & $75,814.17$ & 75.81 \\
\hline
\end{tabular}

Economic valuation of natural resources is an economic tool that uses specific valuation techniques to estimate the monetary value of goods and services provided by natural resources and the environment (Rianse and Abdi 2010; Roslinda et al 2020). The economic valuation of the potential carbon stock in KHDTK of Gunung Bromo used an assumption of a carbon price of USD $10 /$ ton from the voluntary markets. The use of carbon price from voluntary markets has the advantage because it is resulted from the observed market behavior and reflects the average economic income that forest owners could obtain from selling carbon offsets in the market, assuming there are no transaction costs (Naime et al. 2020; Noniini and Fiala 2019). The results of the economic valuation of the carbon in KHDTK of Gunung Bromo are presented in Table 5.

Table 5. Economic valuation of carbon in KHDTK of Gunung Bromo

\begin{tabular}{lcc}
\hline \multirow{2}{*}{ Tree species } & \multicolumn{2}{c}{ Carbon value } \\
\cline { 2 - 3 } & USD/ha & \multicolumn{1}{c}{ IDR/ha* } \\
\hline Pinus merkusii & 497.6 & $7,126,204.24$ \\
Swietenia mahagoni & 173.4 & $2,483,287.41$ \\
Dalbergia latifolia & 6.3 & $90,223.25$ \\
Others & 80.8 & $1,157,148.92$ \\
\hline Total & 758.1 & $10,856,863.80$ \\
\hline
\end{tabular}

Note: *USD 1 = IDR 14,321.15 (Januari 2022).

The results showed that the economic value of potential carbon stock in KHDTK of Gunung Bromo was USD 758.1/ha or equivalent to IDR 10,856,863.80/ha (Table 5). With the growing issue of carbon trading, Indonesia has made a significant contribution to reducing carbon emissions. However, reducing emissions to meet Indonesia's target of a $41 \%$ reduction below business-as-usual levels would require even more substantial efforts, including implementing energy conservation programs and pursuing mitigation measures for other sectors and gases (Wijaya et al. 2017).

The potential carbon sequestration and economic value in KHDTK of Gunung Bromo could increase the mitigation of emission reductions while increasing the country's foreign exchange. Based on the results of this study, KHDTK of Gunung Bromo has a potential carbon economic value, so forest management should be carried out to increase the economic value of the forest through carbon sequestration and environmental services. The utilization of forest areas should not be based on exploitation activities but should be focused on the efforts to protect and maintain the sustainability of forest resources (Arfitryana et al. 2021). The forest management of KHDTK of 
Gunung Bromo could be done by maximizing the economic value of environmental services and natural beauty that can indirectly benefit the communities surrounding the forest. The programs that can be developed at KHDTK of Gunung Bromo to take advantage of biodiversity, landscape beauty, and carbon conservation in the forest are ecotourism such as forest healing tourism, beekeeping, bird watching, and trees adoption. This also could be an opportunity for KHDTK of Gunung Bromo to provide funding in managing and developing educational forests.

\section{Conclusions}

The results showed that the estimated size of carbon stock in KHDTK of Gunung Bromo was 75.81 tonnes $\mathrm{C} / \mathrm{ha}$. The carbon economic value valuation in KHDTK of Gunung Bromo was USD 758.1/ha or equivalent to IDR 10,856,863.80/ha. By knowing the potential of carbon stock and its economic value, the management of KHDTK of Gunung Bromo could enhance the environmental services. KHDTK of Gunung Bromo management can develop programs to take advantage of biodiversity, landscape beauty, and carbon conservation in the forest, namely ecotourism such as forest healing tourism, beekeeping, bird watching, and trees adoption. This also could be an opportunity for KHDTK of Gunung Bromo to provide funding in managing and developing educational forests.

\section{Acknowledgments}

This study was supported by a research grant from the UNS PNBP.

\section{References}

Arfitryana, A., Zulkarnaini, Z., and Warningsih, T. 2021. Nilai Ekonomi Potensi Jasa Lingkungan Menyerap Karbon Di Taman Wisata Alam Buluh Cina Kabupaten Kampar Provinsi Riau. Jurnal Ilmu Lingkungan 15(1): 32-44. DOI: 10.31258/jil.15.1

Bismark, M., Heriyanto, N., and Iskandar, S. 2008. Biomassa dan Kandungan Karbon pada Hutan Produksi di Cagar Biosfer Pulau Siberut, Sumatera Barat. Jurnal Penelitian Hutan dan Konservasi Alam 5(5): 397-407. DOI: 10.20886/jphka.2008.5.5.397-407

Brown, S. 1997. Estimating Biomass and Biomass Change of Tropical Forests: A Primer. FAO. Rome. 87 pp.

Chave, J., Réjou-Méchain, M., Búrquez, A., Chidumayo, E., Colgan, M. S., Delitti, W. B. C., Duque, A., Eid, T., Fearnside, P. M., Goodman, R. C., Henry, M., Martínez-Yrízar, A., Mugasha, W. A., Muller-Landau, H. C., Mencuccini, M., Nelson, B. W., Ngomanda, A., Nogueira, E. M., Ortiz-Malavassi, E., and Vieilledent, G. 2014. Improved Allometric Models to Estimate the Aboveground Biomass of Tropical Trees. Global Change Biology 20(10): 3177-3190. DOI: 10.1111/gcb.12629

Dong, N. T., Tap, V. H., Mai, N. T. P., and Lien, N. T. H. 2020. Estimation of Forest Carbon Stocks in Ba Be National Park, Bac Kan Province, Vietnam. Forest and Society 4(1): 195208. DOI: $10.24259 /$ fs.v4i1.7848

Drupadi, T. A., Ariyanto, D. P., and Sudadi, S. 2021. Pendugaan Kadar Biomassa dan Karbon Tersimpan pada Berbagai Kemiringan dan Tutupan Lahan di KHDTK Gunung Bromo UNS. Jurnal Agrikultura 32(2): 112-119. DOI: 10.24198/agrikultura.v32i2.32344 
Hutajulu, G. B., and Afifah, H. 2019. Nilai Ekonomi Simpanan Karbon Hutan Alam Taman Nasional Way Kambas. BIOTIKA 17(2): 9-19. DOI: 10.24198/biotika.v17i2.26645

Kauffman, J. B., and Donato, D. C. 2012. Protocols for the Measurement, Monitoring, and Reporting of Structure, Biomass, and Carbon Stocks in Mangrove Forests. Working Paper. CIFOR. Bogor. 40 pp.

Kepel, T. L., Suryono, D. D., Ati, R. N., Lesmana, H., and Albertino, A. 2017. Nilai Penting dan Estimasi Nilai Ekonomi Simpanan Karbon Vegetasi Mangrove di Kema, Sulawesi Utara Jurnal Kelautan Nasional 12(1): 19-26. DOI: 10.15578/jkn.v12i1.6170

Khan, M. N. I., Islam, M. R., Rahman, A., Azad, M. S., Mollick, A. S., Kamruzzaman, M., Sadath, M. N., Feroz, S. M., Rakkibu, M. G., and Knohl, A. 2020. Allometric Relationships of Stand Level Carbon Stocks to Basal Area, Tree Height and Wood Density of Nine Tree Species in Bangladesh. Global Ecology and Conservation 22: e01025. DOI: 10.1016/j.gecco.2020.e01025

Ministry of Forestry of Republic Indonesia. 2013. Pedoman Penggunaan Model Alometrik untuk Pendugaan Biomassa dan Stok Karbon Hutan di Indonesia. Pusat Penelitian dan Pengembangan Konservasi dan Rehabilitasi. Badan Penelitian dan Pengembangan Kehutanan - Kementerian Kehutanan. Jakarta.

Naime, J., Mora, F., Martinez, M.S., Arreola, F., and Balvanera, P. 2020. Economic Valuation of Ecosystem Services from Secondary Tropical Forests: Trade-Offs and Implications for Policy Making. Forest Ecology and Management 473: 118294. DOI: 10.1016/j.foreco.2020.118294

Nonini, L., and Fiala, M. 2019. Estimation of Carbon Storage of Forest Biomass for Voluntary Carbon Markets: Preliminary Results. Journal of Forestry Research 32: 329-338. DOI: 10.1007/s11676-019-01074-w

Pebriandi, P., Sribudiani, E., and Mukhamadun, M. 2014. Estimation of the Carbon Potential in the Above Ground at the Stand Level Poles and Trees in Sentajo Protected Forest. Jom Faperta UR 1(1): 1-13.

Perez-Verdin, G., Sanjurjo-Rivera, E., Galicia, L., Hernandez-Diaz, J. C., Hernandez-Trejo, V., and Marquez-Linares, M. A. 2016. Economic Valuation of Ecosystem Services in Mexico: Current Status and Trends. Ecosystem Services 21: 6-19. DOI: 10.1016/j.ecoser.2016.07.003

Peters-Stanley, M. and Hamilton, K. 2012. Developing Dimension: State of the Voluntary Carbon Markets 2012. Ecosystem Marketplace and Bloomberg New Energy Finance.

Rianse, U. and Abdi. 2010. Agroforestri Solusi Sosial dan Ekonomi Pengelolaan Sumber Daya Hutan. Book. Penerbit Alfabeta. Bandung

Rizki, G. M., Bintoro, A., and Hilmanto, R. 2016. Perbandingan Emisi Karbon dengan Karbon Tersimpan di Hutan Rakyat Desa Buana Sakti Kecamatan Batanghari Kabupaten Lampung Timur. Jurnal Sylva Lestari 4(1): 89-96. DOI: 10.23960/js11489-96

Rochmayanto, Y., Darusman, D., and Rusolono, T. 2010. Change of The Carbon Stock and Its Economic Value on the Conversion of Peat Swamp Forest to Pulpwood Industrial Plantation Forest. Jurnal Penelitian Hutan Tanaman 7(2): 93-106. DOI: 10.20886/jpht.2010.7.2.93106

Rochmayanto, Y., Wibowo, A., Lugina, M., Butarbutar, T., Mulyadin, R.M., and Wicaksono, D. 2014. Cadangan Karbon pada Berbagai Tipe Hutan dan Jenis Tanaman di Indonesia. Book. PT. Kanisius. Yogyakarta. 
Roslinda, E., Munir, A., Haryono, A., and Ansyari, A. 2020. Nilai Ekonomi Arboretum Sylva Universitas Tanjungpura Pontianak. Jurnal Sylva Lestari 8(1): 42-53. DOI: 10.23960/js11842-53

Sallata, M. K. 2013. Pinus (Pinus merkusii Jungh et de Vriese) dan Keberadaannya di Kabupaten Tana Toraja, Sulawesi Selatan. Info Teknis EBONI 10(2): 85-98.

Torres, A. B., MacMillan, D. C., Skutsch, M., and Lovett, J. C. 2015. "Yes-in-my-Backyard": Spatial Differences in the Valuation of Forest Services and Local Co-Benefits for Carbon Markets in México. Ecological Economics 109: 130-141. DOI: 10.1016/j.ecolecon.2014.11.008

UNFCCC. 2009. National Economic, Environment and Development Study (NEEDS) for Climate Change. Indonesia Country Study: National Council on Climate Change Republic of Indonesia. United Nations Framework Convention on Climate Change (UNFCC). Jakarta.

UPT Pusdiklathut. 2019. Rencana Pengelolaan KHDTK Gunung Bromo. UPT Pusdiklahut. Malang.

Uthbah, Z., Sudiana, E., and Yani, E. 2017. Analisis Biomasa dan Cadangan Karbon pada Berbagai Umur Tegakan Damar (Agathis dammara (Lamb.) Rich.) di KPH Banyumas Timur. Scripta Biologica 4(2): 119-124. DOI: 10.20884/1.sb.2017.4.2.404

Wardhana, H. F. P. 2011. Pendugaan Potensi Simpanan Karbon pada Tegakan Pinus (Pinus merkusii Jungh. et de Vriese) di KPH Cianjur, Perum Perhutani Unit III Jawa Barat dan Banten. Thesis. Institut Pertanian Bogor. Bogor.

Wijaya, A., Chrysolite, H., Ge, M., Wibowo, C. K., Pradana, A., Utami, A.F., and Austin, K. 2017. How Can Indonesia Achieve Its Climate Change Mitigation Goal? An Analysis Of Potential Emissions Reductions From Energy And Land-Use Policies. Working Paper. World Resources Institute. Jakarta.

Yulistyarini, T., Priyadarshini, R. and Eny. 2009. Potensi Hutan Pinus sebagai Penyimpan Karbon di Kecamatan Ngantang, Kabupaten Malang. Prosiding Seminar Peranan Konservasi Flora Indonesia dalam Mengatasi Dampak Pemanasan Global, 14 Juli 2009. Jakarta.

Yuniawati, and Tampubolon, R. M. 2021. A Decrease in Carbon Absorption Potential Due to Timber Harvesting in Natural Forest. Jurnal Sylva Lestari 9(3): 389-399. DOI: 10.23960/jsl.v9i3.516

Zainuddin, M., and Tahnur, M. 2018. Nilai Manfaat Ekonomi Hutan Kota Universitas Hasanuddin Makassar. Jurnal Hutan dan Masyarakat 10(2): 239. DOI: 10.24259/jhm.v10i2.4874

Zhang, Y., Chen, J., Hu, M., and Offer, A. 2016. Valuation of Forest Carbon Sinks in China within the Framework of the System of National Accounts. Journal of Forestry Research 27(6): 1321-1328. DOI: 10.1007/s11676-016-0253-y 